\title{
RESOURCE USE EFFICIENCY AMONG RICE FARMERS AROUND FRAGILE ECOSYSTEMS: EVIDENCE FROM KILOMBERO WETLAND, TANZANIA
}

\author{
Philip Kamau ${ }^{1}$, Daniel Willy ${ }^{2}$, Lucy Ngare ${ }^{3}$ \\ ${ }^{1,2,3}$ School of Agriculture, Department of Agricultural Economics, Kenyatta University, \\ P.O. Box 43844-00100, Nairobi, Kenya \\ ${ }^{2}$ African Agricultural Technology Foundation (AATF), ILRI Campus, Naivasha Road, \\ P.O. Box 30709-00100, Nairobi, Kenya \\ ${ }^{1}$ Corresponding author: kamaupndehi@gmail.com \\ ${ }^{2}$ kyalodaniel@gmail.com \\ 1'wangare2002@yahoo.com
}

\begin{abstract}
Farmers have been encroaching fragile wetlands as a strategy to increase their rice production thus threatening wetlands' existence and capacity to other critical ecosystem services. This calls for efficient production to strike the balance between food rice production and wetlands' sustainable existence. The current study sought to provide assess rice farmers' technical efficiency of resource use by detecting the determinants of rice yield and further identify the determinants of technical efficiency of the resources used by rice farmers in Kilombero wetland. A cross-sectional survey of 145 randomly sampled farmers aided in achieving the study objective. A stochastic frontier analysis (SFA) model was used to analyze data. The mean technical efficiency among farmers was at $60.54 \%$ level. The positive determinants of rice yield were land and fertilizers while labor influenced it negatively. Age, education, farming experience, group membership, and credit access reduced inefficiency while the distance to the extension agent and off-farm income increased farmers' inefficiency. The study concludes that there is a possibility of expanding rice production without threatening the wetland's existence. It recommends that government and other stakeholders to ensure that rice farmers are up-to-date with optimal use of fertilizers in rice production since it will assist in improving rice yield while the rate of expansion of rice lands in the wetlands will lower. Policy implementers ought to establish initiatives that inspire rice farmers to capitalize on farmer groups and join education programs to take full advantage of their potential efficiency and might participate in community development activities.
\end{abstract}

Keywords: Efficiency, Degradation, Stochastic Frontier Analysis, Wetlands, Fragile ecosystems (JEL code: Q15)

\section{INTRODUCTION}

The second most important staple food crop cultivated in the United Republic of Tanzania is rice (Oryza sativa L.), grown in both Zanzibar and the mainland (Gebeyehu, Kangile, \& Mwakatobe, 2019). Regardless of the increased expansion of the cultivated land under rice, farmers' productivity remains as low as under $2.0 \mathrm{t}$ ha- 1 while they have the potential to produce over 5.6 tha-1 (Sekiya et al., 2013). Low-yielding rice varieties, poor dissemination of technology, and the effects of climate change on the natural environment among other factors have contributed to low rice productivity in Tanzania (Rugumamu, 2014). As part of the intervention strategy, the government in collaboration with other stakeholders introduced NERICA (Oryza glaberrima), which is one of the yield-enhancing varieties (Africa Rice Center (WARDA), 2008). Nevertheless, the introduction of high-yielding varieties to farmers has not improved rice productivity (Styger, 2012). The annual production of rice is about 1.8 million MT while the consumption is approximately 1.9 million MT (USDA, 2017).

Around the Kilombero wetland, the International Rice 
Research Centre (IRRI) and Kilombero Agricultural Training and Research Institute (KATRIN) introduced pest and disease resistance as well as high-yielding varieties such as TXD 88, TXD 305 and Nerica (Styger, 2012). Kilombero Plantation Limited (KPL) in partnership with United States Agency for International Development (USAID) provides inputs to many farmers within the wetland. The Tanzanian government is also expanding rice production within the Kilombero wetland through the Southern Agricultural Growth Corridor of Tanzania (SAGCOT) initiative by establishing 16 irrigation schemes for the next over ten years (Smith, 2016).

Farmers have been encroaching fragile wetlands as a strategy to increase their rice production. The encroachment is a threat to wetlands' existence and capacity to provide other critical ecosystem services despite the success in the increase in output production. The threat in the wetland's ecosystem involves draining water in the wetlands to make arable land from extreme marshes. Leachates, including pesticides and chemical fertilizers, do also affect the wetland fragile ecosystem thus negatively disturbing the stability of the natural fauna and flora. All the interference from agriculture ends up paralyzing soil formation and hydrology, which take place in the wetlands (Turyahabwe et al., 2013).

Unregulated farming activities around the wetlands, if not addressed with speed, will diminish the wetlands and risk the natural habitation of fauna and flora that thrive in marshy ecosystems. The distorted future of the wetlands looms due to loss of vegetation, groundwater reduction, changes in water regimes, and reduced floods (Baldock et al., 2000; Raburu, Okeyo-Owuor, \& Kwena, 2012). Since wetlands will remain a crucial contributor to food security, there is thus a call to improve the efficiency of rice production among farmers around the wetlands to strike a balance between wetland sustainability and food production. Sustainability of the wetlands will result from reduced pressure on wetlands resources due to the increased farmers' productive efficiency as they will not require to expand more land to increase their productive capacity.

Wetlands are known to provide several other critical ecosystem services apart from agricultural production. Such services include the provisioning, supporting, cultural, and regulating services (International Water Management Institute, 2014; Wood, Dixon, \& Mccartney, 2013). Out of all the functions that wetlands play, agriculture emerges as the most important contributor to wetland degradation as some rice producers have permanently transformed the fragile natural ecosystems to unstable land-use regimes. One avenue to control the negative externalities of agriculture on wetlands is the encouragement of farming practices that do not exacerbate wetlands' degradation through efficient production. It is, therefore, crucial to ensure that rice farming is done under the highest technical efficiency (TE).

Technical efficiency denotes the capability of a farm to convert resources (inputs) into outputs ( Toma et al., 2015; Kansiime, van Asten, \& Sneyers, 2018). It depicts the performance in the process of transforming inputs into outputs. It presents the optimality of the conversion process in the event there is no wastage of resources as inputs are converted into outputs. Two forms of efficiency exist namely input-oriented and output-oriented. The input-oriented TE allows farmers to achieve a given output using minimal quantities of inputs at a given technology while the output-oriented TE allows farmers to achieve maximum output using the available quantities of inputs (Hong et al., 2019). Farmers normally strive to achieve output-oriented efficiency due to scarcity of resources. At the farm's technical efficiency frontier, there is absolutely no wastage of resources in the process of production. Farmers rarely produce at the frontier due to unprecedented weather vagaries, pests, and diseases among other random shocks. A measurement of farmers' TE assists in the detection of the production factors that need to be targeted for increased crop productivity while separating farmers' inefficiency from managerial weaknesses.

Efficient production also reduces the magnitude in which agriculture degrades wetlands as the factors of production are used optimally and farmers do not necessarily need to expand their plots into wetlands (Pretty \& Bharucha, 2014). Rice production in Kilombero wetland among other wetlands must be produced efficiently to curb further anthropogenic damage of the wetland. An efficient production will guarantee the minimization of unsustainable agricultural intensification from improper usage of inputs, which mainly causes soil degradation (Willy, Muyanga, \& Jayne, 2019). In the long run, efficient production will ensure that wetlands will continue to sustainably offer other critical ecosystem services along with the provision of resources for food production.

Many studies have directed their focus on the threats faced by wetlands due to anthropogenic activities (Gardner et al., 2015; Halima et al., 2009; McCartney et al., 2010; Schuyt, 2005; Turyahabwe et al., 2013). Urbanization, population pressure, and weather changes amid other aspects have accelerated the anthropogenic damages (FAO \& IWMI, 2017). Despite all the dynamics surrounding the wetlands, the ecosystems have heightened pressure from different competing uses, which calls for efficient production to sustain their capacity to function naturally (Kyalo \& Heckelei, 2018). However, a dearth of scientific studies exists regarding the efficiency of rice production around the Kilombero wetlands, which may form a basis for future wetland sustainability. The dearth exists despite the crucial contribution of wetlands to food security while degradation from agricultural practices continues to threaten the fragile ecosystems' continued existence. This called for a need to carry out a study that would assess rice farmers' technical efficiency of resource use by detecting the determinants of rice yield among the inputs used in output production. There is further need to identify the determinants of technical efficiency of the resources used. We, therefore, carried out a cross-sectional research to address the aforementioned objectives. 


\section{MATERIALS AND METHODS}

\section{The study area, data types, and sampling procedures}

Kilombero wetland is a river floodplain of a valley close to Ifakara in Tanzania stretching over a distance of $250 \mathrm{Km}$ and a width of approximately $65 \mathrm{Km}$ along the banks of the Kilombero River, in the South-central parts of Tanzania. The valley and the marginal hills around it cover approximately $11,600 \mathrm{Km} 2$. This wetland experiences a sub-humid climate and receives a mean of around $1418 \mathrm{~mm}$ of rainfall and 240C of temperature annually (Kato, 2007). Rice, maize, green grams, bananas, and beans are the major crops produced in this wetland. The sampling of the study site was purposive because the Kilombero wetland is a focus floodplain for the Tanzanian government due to its current capacity of sustaining rice production all-year-round (Mombo et al., 2011). The Tanzanian government has a rice production expansion plan through the Kilombero cluster of the Southern Agricultural Growth Corridor of Tanzania (SAGCOT) by establishing 16 irrigation schemes for the next over 10 years (CDM Smith, 2016).

The sampling involved a two-stage method because the wetland is a well defined Ramsar site. First, administrative officers and knowledgeable villagers assisted in listing all the villages located around the wetlands. Secondly, in order to ensure a reasonable representation of households across the entire wetland, villages were randomly sampled. A total of 8 villages were sampled from the list generated around the wetland. A sampling frame was then developed from sampled villages and each village, proportional to its size, contributed to the drawing of a random sample of households giving a sample of 145 rice farmers, which had been obtained using the Kothari, (2004) formula.

\section{Analytical framework}

\section{Measurement of technical efficiency}

Technical efficiency is mainly measured using two methods namely stochastic frontier analysis (SFA) (Aigner et al., 1977) and data envelopment analysis (DEA) (Charnes et al., 1978). The SFA method is a parametric approach while the DEA is a deterministic method that uses linear programming. The latter method assumes that all shortfalls from maximal production output are attributable to the inefficiency of farmers. The DEA has the advantage of being able to incorporate many inputs and outputs in the analysis of efficiency. However, it suffers grave shortcomings due to sensitivity to outliers and computational complexities. The method also overestimates technical efficiency measures due to the failure to account for measurement errors. The current study, therefore, utilized the SFA model as it distinguishes the random variations as a result of statistical noise and inefficiency effects. The SFA model allows for hypotheses testing with regard to the structure of production as well as the level of inefficiency, which is a crucial practice that is not done through DEA (Coelli et al., 2005).

\section{Diagnostic tests}

A statistical test was done on the ordinary least squares (OLS) and SFA model to establish the appropriate model for the study analysis. The test was done by testing a null hypothesis $\left(\mathrm{H}_{0}: \gamma=0\right)$, which implies the non-stochastic nature of the inefficiencies (Ui). A true null reduces SFA to a conventional function (OLS) due to a lack of inefficiency effects. The test uses lambda $(\lambda)$, obtained in equation 1 estimation through the generalized likelihood-ratio method (Battese \& Broca, 1997).

$$
\lambda=-2\left[\ln \left\{\mathrm{L}\left(\mathrm{H}_{0}\right)\right\}-\ln \left\{\mathrm{L}\left(\mathrm{H}_{1}\right)\right\}\right]
$$

where $\mathrm{L}(\mathrm{H} 0)$ and $\{\mathrm{L}(\mathrm{H} 1)$ denote the null and alternative hypotheses respectively. By failing to reject the null hypothesis $\left(\mathrm{H}_{0}: \gamma=0\right)$, lambda $(\lambda)$ assumes a mixed $\chi^{2}$ distribution. Subsequently, an SFA model fails the test as the best analytical method because the error term usually assumes both random effects $\left(V_{i}\right)$ and inefficiency effects $\left(U_{i}\right)$. In such a scenario, OLS remains adequate over SFA and the opposite is right.

\section{Stochastic frontier analysis (SFA)}

Cobb-Douglas (CD) and translog stochastic frontier analyses are the most used common model specifications. Both models were tested for the specification tests of multicollinearity and heteroscedasticity. Multicollinearity was detected using the variance inflation factor (VIF) test such that $V I F_{i}=1 /\left(1-R_{i}^{2}\right)$, where $R_{i}^{2}$ represents an $R^{2}$ in an artificial OLS that treats $\mathrm{i}^{\text {th }}$ explanatory variable as a "dependent" variable (Otieno, Hubbard, \& Ruto, 2012). As a general principle, a value of VIF larger than ten (10) exhibits a problem in data due to multicollinearity (Gujarati, 2004). Secondly, the null hypothesis that assumes homoscedasticity (Var $\varepsilon=\mathrm{E} \mid \varepsilon-$ $\left.\mathrm{E}(\varepsilon) \mathrm{J}=\delta^{2}\right)$ in data was assessed using Breusch-Pagan / CookWeisberg tests. The translog model model was disqualified due to high multicollinearity (see Table 4).

The Cobb-Douglas function of the SFA model by Battese and Coelli (1995) is given as

$\mathrm{Y}_{\mathrm{i}}=\exp \left(\mathrm{x}_{\mathrm{mi}}, \beta_{\mathrm{i}}, \varepsilon_{\mathrm{i}}\right)$

where $\mathrm{i}=1,2, \ldots, \mathrm{m}$ and $\varepsilon_{\mathrm{i}}=\mathrm{V}_{\mathrm{i}}-\mathrm{U}_{\mathrm{i}}, \mathrm{Y}_{\mathrm{i}}$ represents the $\mathrm{i}^{\text {th }}$ farm yield, $\mathrm{x}_{\mathrm{i}}$ is inputs vector for the ith farm and $\beta_{\mathrm{i}}$ are the unknown parameters. The notation $\varepsilon_{\mathrm{i}}$ represents error term composed of random error $\left(\mathrm{V}_{\mathrm{i}}\right)$ that denotes the environmental influence, whose mean and variance $\mathrm{N}\left(0 ; \sigma_{\mathrm{U}}^{2}\right)$ is zero. The notation $\mathrm{V}_{\mathrm{i}}$ is attributed to factors that are beyond farmers' control and errors during model estimation. The term $U_{\mathrm{i}}$ is a random non-negative $\left(\mathrm{U}_{\mathrm{i}} \geq 0\right)$ half-normally distributed $\mathrm{N}\left(0 ; \sigma_{\mathrm{U}}^{2}\right)$ variable that is associated with farm factors and impedes the achievement of maximum production output. 
Two types of stochastic frontier analysis approaches exist, namely one-step and two-step methods. Huang and Liu (1994) proposed a one-step SFA estimation to produce unbiased coefficients of inefficiency determinants compared to a twostep approach by Pitt and Lee (1981). Huang and Liu (1994) assumes $U_{i}$ as truncated-normally distributed and combines production function with the inefficiency model. However, Frohloff, (2007) asserts that under such an assumption, the estimates reflect gross efficiency, which is not completely adjusted for the influence of exogenous variables. The halfnormal distribution of $U_{i}$ assumption solves the shortcoming of the truncated-normal assumption. The half-normal assumption allows the SFA model to include the exogenous variables in the production function, thus obtaining net efficiency (Coelli, Perelman, \& Romano, 1999). The two-step approach suffers from a contradiction that the inefficiency term $\left(U_{i}\right)$ distribution makes different assumptions in both stages. In step one, the the stochastic frontier is estimated by model based on an assumption of half-normal distribution. In the second step, the inefficiency effects assume truncated-normal distribution to allow an estimation of the influence of exogeneous variables on $\left(\mathrm{U}_{\mathrm{i}}\right)$ in a Tobit model. The inconsistency in the inefficiency distribution assumptions results to biased estimated in the second stage. Also, the first step assumes that inefficiency effects $\left(\mathrm{U}_{\mathrm{i}}\right)$ have an independent and identical distribution (iid) but then regress the exogenous variables against the inefficiency indices.

The current study utilized a one-step estimation where $U_{i}$ assumes a half-normal distribution and depends on exogenous factors $Z_{i}$ where $\left(Z_{i}=Z_{1 i}, \ldots, Z_{m i}\right)$. The inefficiency effects model is presented

as $\mathrm{U}_{\mathrm{i}}=\mathrm{Z}_{\mathrm{i}} \delta+\mathrm{W}_{\mathrm{i}}$

where $\mathrm{Z}_{\mathrm{i}}$ represents the exogenous factors that influence the $\mathrm{i}^{\text {th }}$ farm TE, $\delta$ represents the parameters to be estimated, and $\mathrm{W}_{\mathrm{i}}$ represents th residual efficiency presented as the random error. The truncation of $U_{i}$ is at zero with a constant variance $\sigma_{U}^{2}$ and mode $Z_{i}^{\prime} \delta$ changing over the farms. A log-likelihood function that assumes $\mathrm{U}_{\mathrm{i}}$ and $\mathrm{V}_{\mathrm{i}}$ being independently distributed of each other is presented by

$\left.\ln Y_{i} \mid \beta, \lambda, \sigma^{2}\right)=m \ln \frac{\sqrt{2}}{\sqrt{\Pi}}+m \ln \sigma^{-1}+\sum_{i=1}^{m} \ln \left[1-F\left(\varepsilon_{i} \lambda \sigma^{-1}\right)\right]-\frac{1}{2 \sigma^{2}} \sum_{i=1}^{m} \varepsilon_{i}^{2}$

where the term $\varepsilon_{i}$ can be obtained by $Y_{i}-x_{i} \beta$ while $F$ represents the distribution assumption, which is the conditional distribution function (cdf). The equation (4) MLE gives the values of parameters $\beta, \lambda, \sigma$. The TE of the $i^{\text {th }}$ farm is thus expressed in terms of the quotient of the observed production output $\left(\mathrm{Y}_{\mathrm{i}}\right)$ and the highest predicted output (frontier output) $\left(\mathrm{Y}_{\mathrm{i}}^{*}\right.$ ) (Furesi, Madau, \& Pulina, 2013). It is expressed in equation 5 .

$T E_{i}=\frac{Y_{i}}{Y_{i}^{*}}=\frac{\operatorname{Exp}\left(\beta_{0}+\sum_{m} \beta_{m} \ln x_{m i}+V_{i}-U_{i}\right)}{\operatorname{Exp}\left(\beta_{0}+\sum_{m} \beta_{m} \ln x_{m i} V_{i}\right.}=\operatorname{Exp}\left(-U_{i}\right)$
Technical inefficiency is then $1-\mathrm{TE}_{\mathrm{i}}$ and TE prediction requires that $\mathrm{U}_{\mathrm{i}}$ should be estimated.

Equation 6 shows the estimation of the conditional expected value of $U_{i}$ that best predicts $U_{i}$ given $\varepsilon_{i}$.

$E(U \mid \varepsilon)=\sigma_{*}\left[\frac{f(\varepsilon \lambda / \sigma)}{1-F(\varepsilon \lambda / \sigma)}-\left(\frac{\varepsilon \lambda}{\sigma}\right)\right]$

From equation $6, \lambda=\sigma_{U} / \sigma_{V^{\prime}} \varepsilon \lambda=-U_{*} / \sigma_{*}$, and $f$ is the normal density function (Jondrow et al., 207 1982). The notations $\sigma_{*}$ and $U_{*}$ are unobservable thus they are replaced by their respective estimates 208 giving technical efficiency as

$T E_{i}=E\left[\left(\exp \left(-U_{i} \mid \varepsilon_{i}\right]=\left\{\frac{1-\Phi\left[\sigma_{*}-\left(U_{i}^{*} / \sigma_{*}\right)\right]}{1-\Phi\left(-U_{i}^{*} / \sigma_{*}\right)}\right\} \exp \left(-U_{i}^{*}+\frac{1}{2} \sigma_{*}^{2}\right)\right.\right.$

where $\Phi$ represents the cumulative density function (Battese \& Coelli, 1988).

\section{Model specification}

Table 1: Description of the one-step SFA model variables

\begin{tabular}{|c|c|c|}
\hline Variable & Description & Measurement \\
\hline \multicolumn{3}{|c|}{ Dependent } \\
\hline Y_i & Output per hectare (in model 1) & Kg ha-1 \\
\hline U_i & Technical inefficiency (in model 2) & Index $(0-1)$ \\
\hline \multicolumn{3}{|c|}{ Independent } \\
\hline \multicolumn{3}{|c|}{ Model 1} \\
\hline $\mathrm{X} 1$ & Plot size under rice & $\mathrm{Ha}$ \\
\hline $\mathrm{X} 2$ & $\begin{array}{c}\text { Family and hired labor using } \\
\text { adult equivalent }\end{array}$ & Man-days ha-1 \\
\hline $\mathrm{X} 3$ & Seeds & Kg ha-1 \\
\hline $\mathrm{X} 4$ & Basal fertilizer & Kg ha-1 \\
\hline $\mathrm{X} 5$ & Topdressing fertilizer & Kg ha-1 \\
\hline $\mathrm{X} 6$ & Pesticides & Litre ha-1 \\
\hline $\mathrm{X} 7$ & Herbicides & Litre ha-1 \\
\hline \multicolumn{3}{|c|}{ Model 2} \\
\hline Z_1 & Household head gender & Male $=1$, Female $=0$ \\
\hline Z_2 & Household head age & Years \\
\hline Z_3 & Education of the household head & Years \\
\hline Z_4 & Household size & Number of persons \\
\hline Z_5 & Rice farming experience & Years \\
\hline Z_6 & $\begin{array}{l}\text { Distance to the nearest } \\
\text { extension service provider }\end{array}$ & Kilometres \\
\hline Z_7 & Access to agricultural credit & Yes $=1, \mathrm{No}=0$ \\
\hline Z_8 & $\begin{array}{l}\text { If a household head belonged to } \\
\text { an organized group }\end{array}$ & Yes $=1, \mathrm{No}=0$ \\
\hline Z_9 & Annual off-farm income & EURO \\
\hline Z_10 & Product market access & Kilometres \\
\hline
\end{tabular}

The stochastic frontier analysis model of the production function in equation 2 was specified as

$\ln Y_{i}=\beta_{0}+\sum_{m=1}^{7} \beta_{m} \ln X_{m i}+v_{i}-u_{i}$ 
where $\ln =$ natural logarithm, $\beta_{0} \beta_{\mathrm{mi}}=$ parameters to be estimated, $\mathrm{i}=\mathrm{i}^{\text {th }}$ farm, $\mathrm{m}=\mathrm{m}^{\text {th }}$ input, $\mathrm{Y}^{\mathrm{i}}=$ farm yield, $\mathrm{X}$ $=$ the production factors (see Table 1), $\mathrm{u}_{\mathrm{i}}=$ the error term's component of inefficiency, and $\mathrm{v}_{\mathrm{i}}$ represents the random error term.

The one-step SFA inefficiency model specification of equation 3 was given by

$$
U_{i}=\delta_{0}+\sum_{m=1}^{10} \delta_{m} Z_{m i}+W
$$

where $\mathrm{U}_{\mathrm{i}}$ represents technical inefficiency, $\delta_{\mathrm{m}}=$ unknown parameters, and $\mathrm{Z}_{\mathrm{mi}}=$ determinants of inefficiency (see Table 1).

\section{RESULTS AND DISCUSSION}

\section{Descriptive statistics}

Table 2 shows the household head's mean age of approximately 53 years and a farming experience of about 23 years. The farming experience shows that a rice producer within the Kilombero wetlands had begun to make independent farming decisions on rice farming at an approximate age of 20 years. The schooling years in formal education was about 13 years which matches the secondary school education. A household had approximately 5 persons and hectares of farmland each. A household head had an average of EUR 125. Lastly, distances to the nearest extension service provider and the product markets were about 11 and 10 $\mathrm{Km}$ respectively.

Table 2: Selected continuous and categorical variables from the study

\begin{tabular}{|c|c|c|c|c|}
\hline Variable & $\begin{array}{c}\text { Mean } \\
(\mathrm{N}=145)\end{array}$ & Std. Dev & Min & Max \\
\hline Age & 53.57 & 12.01 & 26 & 79 \\
\hline Household size & 5.01 & 1.82 & 1 & 10 \\
\hline Education & 12.97 & 4.3 & 0 & 18 \\
\hline Experience & 22.76 & 11.08 & 3 & 50 \\
\hline $\begin{array}{l}\text { Distance to extension } \\
\text { provider }\end{array}$ & 10.74 & 6.73 & 1 & 28 \\
\hline $\begin{array}{l}\text { Distance to the } \\
\text { market }\end{array}$ & 10.19 & 5.92 & 1 & 28 \\
\hline Off-farm income & 125.1 & 61.92 & 0 & 200 \\
\hline Farm size in hectares & 5.25 & 5.38 & 0.5 & 30 \\
\hline & \multicolumn{2}{|c|}{ Freq $(\mathrm{N}=145)$} & \multicolumn{2}{|c|}{ Percent $(\%)$} \\
\hline \multicolumn{5}{|l|}{ Gender } \\
\hline Female & \multicolumn{2}{|c|}{23} & \multicolumn{2}{|c|}{15.9} \\
\hline Male & \multicolumn{2}{|c|}{122} & \multicolumn{2}{|c|}{84.1} \\
\hline \multicolumn{5}{|l|}{ Group membership } \\
\hline No & \multicolumn{2}{|c|}{46} & \multicolumn{2}{|c|}{31.7} \\
\hline Yes & \multicolumn{2}{|c|}{99} & \multicolumn{2}{|c|}{68.3} \\
\hline \multicolumn{5}{|l|}{ Credit access } \\
\hline No & \multicolumn{2}{|c|}{52} & \multicolumn{2}{|c|}{35.9} \\
\hline Yes & \multicolumn{2}{|c|}{93} & \multicolumn{2}{|c|}{64.1} \\
\hline
\end{tabular}

Source: Survey data
The majority (84.1) of the household heads were male. Many of the household heads belonged to groups (68.3\%) and accessed agricultural credits (64.1\%) in cash and kind (such include seeds, pesticides, and fertilizers among others).

Table 3 shows the descriptive results for inputs used and yield attained in rice production in Kilombero wetland.

Table 3: Inputs use and yield among rice farmers

\begin{tabular}{lcccc}
\hline Variable & $\begin{array}{c}\text { Mean } \\
(\mathrm{N}=145)\end{array}$ & Std. Dev & Min & Max \\
\hline Seeds & 61.27 & 28.84 & 9.38 & 185.25 \\
Basal fertilizers & 76.36 & 95.49 & 0.25 & 625 \\
Topdressing & 85.22 & 115.61 & 0.25 & 234.86 \\
fertilizers & 53.05 & 46.81 & 0.49 & 275.9 \\
Labor & 3.25 & 3.28 & 0.12 & 24.7 \\
Pesticides & 2.3 & 1.33 & 0.12 & 7.41 \\
Herbicides & 1.69 & 1.9 & 0.2 & 16 \\
Area under rice & 1054.13 & 605.77 & 55.58 & 4322.5 \\
Yield & \multicolumn{5}{l}{ Source: Survey data } &
\end{tabular}

Seeds quantity was about $61 \mathrm{~kg}$ ha-1 among the wetland rice farmers and the rate concurs with the recommended seed rate of 60-80 kg ha-1 in Tanzania (Global Yield Gap, 2013; United Republic of Tanzania, 2007; Wilson \& Lewis, 2015). Additionally, the basal fertilizers quantities were lower according to the recommended rates of $123.5-130 \mathrm{~kg}$ ha- 1 in Tanzania (IRRI, 2012; United Republic of Tanzania, 2007). Similarly, the topdressing fertilizers quantities were also lower in comparison with the endorsed rate of 87- $260 \mathrm{~kg}$ ha-1 (Africa Rice Center (WARDA), 2008). The number of person-days (53) used in the wetland rice production was smaller compared with the findings of Oumarou \& Huiqiu, (2016) and Kadiri et al., (2014) in Southwestern Niger and Niger Delta of Nigeria respectively, where the respective number of man-days used in rice production averaged at 162 and 180 person-days ha-1. Mechanization of rice production in Kilombero wetland, especially during the planting period, might have contributed to the reduced labor as about $65 \%$ of the rice farmers used tractors for land preparation. Moreover, rice yield was lower than the national mean of about $1.5 \mathrm{t}$ ha-1 (Ngailo et al., 2016; Wilson \& Lewis, 2015).

\section{Empirical model}

\section{Validation tests}

Estimation of equation 1 gave the calculated statistics ( $(02=$ 46.004) that was more than the critical value $(\square 2(1)=2.706)$ thus the study rejected (H0: $\square=0$ ). SFA was thus proven as the appropriate model for the assessment of efficiency and its determinants. The $\square 2$ tests were guided by the critical values in Kodde and Palm (1986). Following the test for appropriateness of SFA over OLS, a test for multicollinearity and heteroscedasticity on Cobb-Douglas and translog specifications of the SFA model was done. Table 4 presents the aforementioned results. 
Table 4: Tests of multicollinearity and heteroscedasticity in the onestep translog and Cobb-Douglas specifications

\begin{tabular}{lcccc}
\hline Model & $\begin{array}{c}\text { Specification } \\
\text { violation }\end{array}$ & Test type & $\begin{array}{c}\text { Test } \\
\text { results }\end{array}$ & Conclusion \\
\hline \multirow{2}{*}{ Translog } & $\begin{array}{c}\text { Multicollinearity } \\
\text { Heteroscedasticity }\end{array}$ & $\begin{array}{c}\text { Mean VIF } \\
\text { Breusch-Pagan / } \\
\text { Cook-Weisberg }\end{array}$ & $\begin{array}{c}190.13 \\
2.29\end{array}$ & $\begin{array}{c}\text { High } \\
\text { multicollinearity } \\
\text { Homoscedastic }\end{array}$ \\
\hline \multirow{2}{*}{$\begin{array}{l}\text { Cobb- } \\
\text { Douglas }\end{array}$} & Multicollinearity & Mean VIF & 1.79 & $\begin{array}{c}\text { No } \\
\text { Beteroscedasticity } \\
\text { Breusch-Pagan / } \\
\text { Cook-Weisberg }\end{array}$ \\
\hline
\end{tabular}

Individual and mean VIF values in the Cobb-Douglas specification were all less than 10 . The translog model revealed large values of individual and mean VIFs with the mean value being 190.13. As a general principle, a value of VIF larger than ten (10) exhibits a problem in data due to multicollinearity (Gujarati, 2004). The $\chi 2$ values from the Breusch-Pagan / Cook-Weisberg tests in both specifications were insignificant $(\mathrm{p}>0.05)$.

\section{One-step SFA estimation}

Table 5: One-step SFA results for the production and inefficiency functions

\begin{tabular}{lllll}
\hline Variable & Coefficient & Std. Error & $\mathrm{z}$ & P-value \\
\hline \multicolumn{5}{c}{ Model 1 (Production function) } \\
\hline Land & $0.384^{* * *}$ & 0.023 & 16.88 & 0.000 \\
Seeds & -0.002 & 0.042 & -0.05 & 0.961 \\
Basal fertilizer & $0.171^{* * *}$ & 0.024 & 6.94 & 0.000 \\
Topdressing fertilizer & $0.068^{* * *}$ & 0.017 & 3.90 & 0.000 \\
Labor & $-0.052^{* *}$ & 0.024 & -2.09 & 0.037 \\
Pesticides & 0.001 & 0.012 & 0.08 & 0.936 \\
Herbicides & -0.019 & 0.019 & -1.01 & 0.314 \\
cons & $6.875^{* * *}$ & 0.215 & 31.96 & 0.000 \\
Log likelihood & $-8.114^{* * *}$ & & & \\
Wald chi2 $(8)$ & $468.51^{* * *}$ & & & \\
Prob $>$ Chi ${ }^{2}$ & 0.000 & & & \\
LR test of $\sigma_{\mu}=0:$ & $282.385^{* * *}$ & & & \\
Chibar ${ }^{2}(01)$ & & & & \\
Prob $>=\operatorname{chibar}^{2}$ & 0.000 & & & \\
Gamma $(\gamma)$ & $0.9616^{* * *}$ & 0.0172 & & \\
TE & 0.6054 & 0.2636 & & \\
& & & &
\end{tabular}

\begin{tabular}{lllll}
\hline \multicolumn{5}{c}{ Model 2 (Technical inefficiency model) } \\
\hline Age & $-0.042^{* * *}$ & 0.015 & -2.76 & 0.006 \\
Gender & -0.124 & 0.392 & -0.32 & 0.752 \\
Household size & -0.065 & 0.08 & -0.81 & 0.419 \\
Education & $-0.125^{*}$ & 0.064 & -1.94 & 0.052 \\
Farming experience & $-0.142^{* * *}$ & 0.021 & -6.71 & 0.000 \\
Group membership & $-0.598^{*}$ & 0.325 & -2.96 & 0.066 \\
Credit access & $-0.973^{* * *}$ & 0.329 & -2.96 & 0.003 \\
Extension access & $0.066^{* * *}$ & 0.025 & 2.71 & 0.007 \\
Market access & -0.013 & 0.029 & -0.44 & 0.658 \\
Off-farm income & $0.012^{* * *}$ & 0.004 & 2.63 & 0.008 \\
cons & $4.411^{* * *}$ & 1.336 & 3.30 & 0.001 \\
sigma_v $\left(\sigma_{v}\right)$ & $0.095^{* *}$ & 0.014 & & \\
\hline
\end{tabular}

Notes titles $* * * p<0.01, * * p<0.05, * p<0.1$

Gamma $(\gamma)$, the variance ratio is derived from $\{\sigma \mu 2 /(\sigma \mu 2+\sigma v 2)\}$ or $\{\sigma \mu 2 / \sigma 2\}$
The estimation of maximum likelihood in the overall model in equations 8 and 9 reveals that the had a log-likelihood value of -8.114 and the Wald $\mathrm{Chi}^{2}$ was 468.51 , which was strongly significant $(\mathrm{p}<0.01)$ at $1 \%$ level. The significance of Wald $\mathrm{Chi}^{2}$ displays the precision of model specification demonstrating the joint capability of the explanatory variables in explaining the variations in rice yield.

Inefficiencies in the model were proved by the value of $\gamma$, which infers that $96.16 \%$ of the disparities in rice yield originated from technical inefficiency. The value of $\gamma$ also supports the null hypothesis $\left(\mathrm{H}_{0}: \gamma=0\right)$ rejection that assumes an absence of inefficiencies in the SFA model, which reduces it to OLS. The Likelihood-ratio test had a value of 282.385 , which verified the presence of rice production technical inefficiency in East African wetlands since it was significantly different from zero $(p=0.000)$.

\section{Production factors influencing rice yield}

The findings from Table 5 show that land was a strong positive determinant of rice yield within the Kilombero wetland $(\mathrm{p}<0.01)$. These findings coincide with those reported by Kadiri et al., (2014) in Nigeria's Niger Delta region for paddy rice farming and Islam \& Kalita, (2016) in the West Garo district of Meghalaya state (India) for wetland rice cultivation. The findings indicate that Kilombero wetland is underused, which means that rice farmers have room to expand their output as they have only utilized $32 \%$ of the total farm sizes. It also suggests that initiatives such as the SAGCOT project's Kilombero cluster will implement the expansion of rice production in Kilombero wetland sustainably because the wetland is not overused. The sustainability of wetlands requires reduced drainage from the expansion of agricultural lands into the wetland while operating on the highest production frontier (Kyalo \& Heckelei, 2018). Both planting and topdressing fertilizers were strongly influencing rice yield and were underused $(p<0.01)$. These revelations concurred with the findings of Kadiri et al. (2014) and Oumarou \& Huiqiu, (2016) for rice production in Niger Delta and South-western Niger regions of Nigeria respectively. There is therefore room to attain maximum rice productivity by increasing both planting and topdressing fertilizers. This is because $1 \%$ increase in planting and topdressing fertilizers will increase rice yield by $0.17 \%$ and $0.07 \%$ respectively. Addressing the use of fertilizers to the optimal levels can be a strategy for increasing rice yield on smaller wetland farms while reducing the threat of wetland existence due to rampant encroachment.

Labor was a significant negative determinant of yield $(\mathrm{p}<0.05)$. Such findings coincide with those of (Yang, Mugera, \& Zhang, 2016). The current results show overuse of manpower was allocated than required in making and maintaining of canals as well as engaging in rice production activities. Extra manpower can be used in off-farm activities to boost farmers capability to purchase inputs that will improve the yields. An increase in efficiency means that extra manpower may be allocated elsewhere off the rice production enterprise for a diversity of livelihood. 


\section{Distribution of efficiency scores among rice farmers}

Fig 1 shows that the majority (40.7\%) of rice farmers had efficiency scores ranging from $75-100 \%$ levels. The mean, highest, and lowest scores were $60.54 \%, 96.59 \%$, and $3.13 \%$ respectively. The mean efficiency was close to $62.6 \%$ and $61 \%$ obtained by Kadiri et al. (2014) and Onyenweaku \& Ohajianya (2005) for rice producers in Niger Delta and the Ebonyi state of Nigeria respectively. A rice farmer with at the mean efficiency $(60.54 \%)$ would reduce inputs proportionally up to $37.29 \%$ as given by [(1-(60.54/96.59)) x 100], to operate on the wetland's best frontier of $96.59 \%$ TE.

Figure 1: Efficiency distribution among rice farmers by percentage

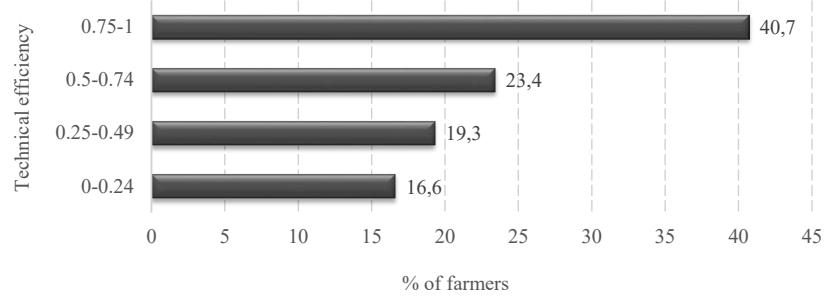

Less than half of the sampled farmers had TE below $50 \%$ perhaps due to the availability of water that cushions them from the risks that emanate from water scarcity. They also have room to improve their efficiency especially if they address the issues related to the usage of other production and non-production factors.

\section{Determinants of efficiency among rice farmers}

Age reduced technical inefficiency significantly $(\mathrm{p}<0.01)$ by $4.2 \%$. This is this infers that older rice farmers in the wetland were more efficient compared to their younger counterparts. As farmers grow older, they advance their agricultural skills and can make decisive farming verdicts regarding efficient inputs use (Dessale, 2019; Mengui, Oh, \& Lee, 2019). The accumulated skills and knowledge combined physical capability which gives older farmers the advantage of accepting new technologies over their younger counterparts. Additionally, farming experience $(p<0.01)$ and formal education $(p<0.1)$ in the Kilombero wetland had a significantly negative influence on inefficiency. More educated farmers are thus efficient as they may have gained the ability to utilize the available agricultural information and technologies (Ahmed, Haji, \& Geta, 2013; Thabethe \& Mungatana, 2014; Dessale, 2019). Regarding farming experience, an extra year expended on rice production gave farmers in the wetland a prospect to significantly raise their efficiency by $14.2 \%$. Oumarou and Huiqiu (2016) elucidated that farmers with several years of planting a certain crop can forecast precisely when to plant, the suitable cropping materials, and types and amounts of production inputs. They may also be knowledgeable about various wetland conservation activities.
Credit access $(\mathrm{p}<0.01)$ and belonging to organized groups $(\mathrm{p}<0.1)$ and negatively influenced inefficiency among rice farmers in Kilombero wetland. Ahmed and Melesse (2018) explained that group membership especially in cooperatives positively determined participation of farmers in off-farm activities which eventually influence efficiency positively. Wetland rice farmers in farmer associations or groups can access linkage to product markets, agricultural training, and input credits among others. This improves their productivity due to the proper and efficient allocation of resources. Group membership may also increase farmers' chances of engaging in collective action on wetland conservation activities. Regarding credit access, Ahmed et al. (2015) and Haile (2015) also found credit access being a positive determinant of efficiency. Sibiko (2012) explained that agricultural credit increases the farmer's capacity to afford yieldimproving inputs, for instance, improved seeds, fertilizers, and labor-saving inputs such as herbicides.

Long distances to the extension service provider and offfarm income positively influenced technical inefficiency $(\mathrm{p}<0.01)$. Longer distances negatively influence efficiency especially when rice farms are in areas where feeder roads are impenetrable and thus it becomes hard for the extension officers to make a considerable number of official visits to farms. The findings of off-farm income concur with those by Tolga et al. (2009) for rice production in Turkey but contradict those by Malinga et al. (2015) and Wakili \& Isa (2015) who found off-farm income to influence efficiency positively. Islam et al. (2012) explained off-farm income rises the farmers' likelihood of adopting new technologies such as improved seeds faster than their counterparts are. However, in the current study we borrow the explanation of Tolga et al., (2009) that as people earn higher off-farm income, they are likely to spend less time in agriculture as they venture into non-agricultural and less risky enterprises.

\section{CONCLUSIONS AND POLICY IMPLICATIONS}

The land was the key factor that influenced rice yield which is underused, and as such, expansion of rice production in Kilombero wetland is possible without threatening the wetlands' existence considering other production inputs. This is because the general farm sizes in Kilombero wetland were less than $50 \%$ utilized. This as well buttresses the sustainability in the expansion of rice production particularly in the Tanzanian government's schemes like the Southern Agricultural Growth Corridor of Tanzania (SAGCOT) program that will see the expansion of rice production within the Kilombero wetland. Farmers that are formally educated and were members of organized groups had prospects of maximizing their efficiency. Longer distances to the nearest extension service providers were detrimental to farmers' efficiency. Off-farm income caused rice producers to concentrate less on the enterprise.

The study recommends that government and other stakeholders to ensure that rice farmers are up-to-date with optimal use of fertilizers in rice production since it will assist in 
improving rice yield as the rate of expansion of rice lands in the wetlands lowers. Action must, therefore, be taken to guarantee the accessibility of extension services among rice farmers. The extension officers should encourage farmers with high off-farm income to capitalize on their capacity to afford yield-enhancing inputs to create a stable rice enterprise. The government policies should encourage rice farmers, irrespective of their age to enroll in technical and vocational courses related to gain a formal education. Formal education will guarantee an increase in farmers' technical efficiency as they will be able to understand different aspects of rice production due to smooth interactions with extension officers. Policy implementers ought to establish programs that inspire rice farmers to exploit farmer groups to take full advantage of their potential efficiency and might participate in community development activities.

\section{ACKNOWLEDGEMENTS}

The authors acknowledge the German Federal Ministry of Education for funding the Master's thesis research.

\section{REFERENCES}

Africa Rice Center (WARDA). (2008). Growing lowland rice. In Africa Rice Center, (WARDA). A production handbook, Africa Rice Center (WARDA), Mikocheni Agricultural Research Institute, Dar es Salaam, Tanzania. 40 p.

Ahmed, B., Haji, J., \& Geta, E. (2013). Analysis of farm households' technical efficiency in production of smallholder farmers: the case of Girawa district, Ethiopia. AmericanEurasian Journal of Agricultural \& Environmental Sciences, 13(12), 1615-1621. https://doi.org/10.5829/idosi. aejaes.2013.13.12.12310

Ahmed, Musa H, Lemma, Z., \& Endrias, G. (2015). Measuring Technical, Economic, and Allocative Efficiency of Maize Production in Subsistence Farming : Evidence from the Central Rift Valley of Ethiopia. Applied Studies in Agribusiness and Commerce - APSTRACT, 9(3), 63-74. https://doi.org/10.19041/APSTRACT/2015/3/9

Ahmed, Musa Hasen, \& Melesse, K. A. (2018). Impact of off-farm activities on technical efficiency: evidence from maize producers of eastern Ethiopia. Agricultural and Food Economics, 6(1). https://doi.org/10.1186/s40100-018-0098-0

Aigner, D., Lovell, C. A. K., \& Schmidt, P. (1977). Formulation and estimation of stochastic frontier production models. Journal of Econometrics 6, 6(1977), 21-37.

Baldock, D., Caraveli, H., Dwyer, J., Einschütz, S., Peteresen, J. E., Sumpsi-Vinas, J., \& Varela-Ortega, C. (2000). The environmental impacts of irrigation in the European Union. In Studies and Reports on Agriculture, European Commission (Vol. 5210). Retrieved from http://ec.europa.eu/environment/
agriculture/pdf/irrigation_xs.pdf\%5Cnhttp://ec.europa.eu/ environment/agriculture/studies.htm

Battese, G. E., \& Broca, S. S. (1997). Functional Forms of Stochastic Frontier Production Functions and Models for Technical Inefficiency Effects: A Comparative Study for Wheat Farmers in Pakistan. Journal of Productivity Analysis, 8(4), 395-414. https://doi.org/10.1023/A:1007736025686

Battese, G. E., \& Coelli, T. J. (1988). Prediction of firm-level technical efficiencies with a generalized frontier production function and panel data. Journal of Econometrics, 38(3), 387-399. https://doi.org/10.1016/0304-4076(88)90053-X

Battese, G. E., \& Coelli, T. J. (1995). A model for technical inefficiency effects in a stochastic frontier production function for panel data. Empirical Economics, 20(2), 325-332. https:// doi.org/10.1007/BF01205442

CDM Smith. (2016). Environmental Flows in Rufiji River Basin Assessed from the Perspective of Planned Development in Kilombero and Lower Rufiji Sub-Basins. Report to the United States Agency for International Development. 146p.

Charnes, A., Cooper, W. W., \& Rhodes, E. (1978). Measuring the efficiency of decision making units. European Journal of Operational Research, 2(6), 429-444. https://doi. org/10.1016/0377-2217(78)90138-8

Coelli, T. J., Rao, D. S. P., O’Donnell, C. J., \& Battes, G. E. (2005). An introduction to efficiency and productivity analysis. In Biometrics (Vol. 41). https://doi.org/10.2307/2531310

Coelli, T., Perelman, S., \& Romano, E. (1999). Accounting for Environmental Influences in Stochastic Frontier Models: With Application to International Airlines. Journal of Productivity Analysis, 11(3), 251-273. https://doi. org/10.1023/A:1007794121363

Dessale, M. (2019). Analysis of technical efficiency of smallholder wheat-growing farmers of Jamma district, Ethiopia. Agriculture \& Food Security, 8(1), 1-8. https:// doi.org/10.1186/s40066-018-0250-9

FAO \& IWMI. (2017). Water pollution from agriculture: a global review. A report by the Food and Agriculture Organization of the United Nations (FAO), and the International Water Management Institute (IWMI), 2017.

Frohloff, A. (2007). Cost and Technical Efficiency of German Hospitals - A Stochastic Frontier Analysis. RheinischWestfälisches Institut für Wirtschaftsforschung (RWI), Essen.

Furesi, R., Madau, F. A., \& Pulina, P. (2013). Technical efficiency in the sheep dairy industry: an application on the Sardinian (Italy) sector. Agricultural and Food Economics, 1(1), 1-11. https://doi.org/10.1186/2193-7532-1-4 
Gardner, R. C., Barchiesi, S., Beltrame, C., Finlayson, C. M., Galewski, T., Harrison, I., ... Walpole, M. (2015). State of the World's Wetlands and Their Services to People: A Compilation of Recent Analyses. https://doi.org/10.2139/ ssrn. 2589447

Gebeyehu, S., Kangile, J., \& Mwakatobe, E. (2019). Development in Practice Assessment of seed quality along the rice seed value chain in Tanzania. Development in Practice, 29(7), 854-866. https://doi.org/10.1080/09614524.2019.164 1181

Global Yield Gap. (2013). Information from collected literature for Nigeria to be used for crop modelling for Tanzania. A report for crop growth calendar, yields, and crop growth patterns, FAO.

Gujarati, D. (2004). Basic Econometrics (4th ed.). New York: McGraw-Hill Companies.

Haile, B. T. (2015). Determinants of technical, allocative and economic efficiencies among onion producing farmers in irrigated agriculture : Empirical evidence from Kobo district, Amhara region, Ethiopia. African Journal of Agricultural Research, 10(20), 2180-2189. https://doi. org/10.5897/AJAR2015.9564

Halima, K. Hassan \& Munishi, K. P. (2009). Contribution of wetlands to household income and food security in the nyumba ya Mungu wetland system, Nothern Tanzania. Tanzania Journal of Forestry and Nature Conservation, 79(2).

Hong, Y., Heerink, N., Zhao, M., \& van der Werf, W. (2019). Intercropping contributes to a higher technical efficiency in smallholder farming: Evidence from a case study in Gaotai County, China. Agricultural Systems, 173(January), 317324. https://doi.org/10.1016/j.agsy.2019.03.007

Huang, C. J., \& Liu, J. T. (1994). Estimation of a nonneutral stochastic frontier production function. Journal of Productivity Analysis, 5(2), 171-180. https://doi.org/10.1007/ BF01073853

International Water Management Institute. (2014). Wetlands and people. Colombo, Sri Lanka: International Water Management Institute (IWMI). 32p. DOI: 10.5337/2014.202 /.

IRRI. (2012). Good agricultural practices for irrigated and rainfed lowland rice in East Africa. Bulletin No. 1, IRRITanzania, Dar es Salaam. 36 p.

Islam, K. M. Z., Sumelius, J., \& Bäckman, S. (2012). Do differences in technical efficiency explain the adoption rate of HYV rice ? Evidence from Bangladesh. Agricultural Economics Review, 13(1), 93-110.
Islam, M., \& Kalita, D. C. (2016). Technical and economic efficiency of resource use in wetland rice cultivation. International Journal of Agricultural Sciences, 6(2), 938-948.

Jondrow, J., Knox Lovell, C. A., Materov, I. S., \& Schmidt, P. (1982). On the estimation of technical inefficiency in the stochastic frontier production function model. Journal of Econometrics, 19(2-3), 233-238. https://doi.org/10.1016/03044076(82)90004-5

Kadiri, F. A., Eze, C. C., Orebiyi, J. S., Lemchi, J. I., Ohajianya, D. O., \& Nwaiwu, I. U. (2014). Technical Efficiency in Paddy Rice Production in Niger Delta Region of Nigeria. Global Journal of Agricultural Research, 2(2), 33-43.

Kadiri, F. A., Eze, C. C., Orebiyi, J. S., Lemchi, J. I., Ohajianya, D. O., \& Nwaiwu, I. U. (2014). Technical efficiency in paddy rice production in Niger Delta Region of Nigeria. Global Journal of Agricultural Research, 2(2), 33-43.

Kansiime, M. K., van Asten, P., \& Sneyers, K. (2018). Farm diversity and resource use efficiency: Targeting agricultural policy interventions in East Africa farming systems. NJAS Wageningen Journal of Life Sciences, 85(April 2016), 32-41. https://doi.org/10.1016/j.njas.2017.12.001

Kato, F. (2007). Development of a major rice cultivation area in the Kilombero Valley, Tanzania. African Study Monographs, 36(March), 3-18.

Kodde, D. A., \& Palm, F. C. (1986). Wald Criteria for Jointly Testing Equality and Inequality Restrictions. Econometrica, 54(5), 1243-1248.

Kothari, C. R. (2004). Research Methodology: Methods and Techniques. New Delhi: New Age International (P) Limited.

Kyalo, W. D., \& Heckelei, T. (2018). Assessment of agricultural intensification and determinants of the relative choice of land management systems in East African wetlands. African Journal of Rural Development, 3(3: July-September 2018), 821-830.

Malinga, N. ., Masuku, M. ., \& Raufu, M. . (2015). Comparative Analysis of Technical Efficiencies of Smallholder Vegetable Farmers with and Without Credit Access in Swazil and the Case of the Hhohho Region. International Journal of Sustainable Agricultural Research, 2(4), 133-145. https://doi. org/10.18488/journal.70/2015.2.4/70.4.133.145

McCartney, M., Rebelo, L.-M., Sellamuttu, S. S., \& Sanjiv de Silva. (2010). Wetlands, Agriculture, and Poverty Reduction. Colombo, Sri Lanka: International Water Management Institute. 39p. (IWMI Research Report 137). DOI: 10.5337/2010.230 /.

Mengui, K. C., Oh, S., \& Lee, S. H. (2019). The Technical Efficiency of Smallholder Irish Potato Producers in Santa Subdivision, Cameroon. Agriculture, 9(256), 1-13. 
Mombo, F., Speelman, S., Huylenbroeck, G. Van, Hella, J., \& Moe, S. (2011). Ratification of the Ramsar convention and sustainable wetlands management : Situation analysis of the Kilombero Valley wetlands in Tanzania. Journal of Agricultural Extension and Rural Development, 3(9), 153-164.

Ngailo, J. A., Mwakasendo, J. A., Kisandu, D. B., Mlowe, F. C., \& Tippe, D. E. (2016). Rice farming in the southern highlands of Tanzania: management practices, socioeconomic roles, and production constraints. European Journal of Research in Social Sciences, 4(4), 28-39.

Onyenweaku, C.E. Ohajianya, D. O. (2005). Technical efficiency of Rice farmers in Ebonyi State, Nigeria. Journal of Agriculture and Food Science, 3(2), 175-184.

Otieno, D. J., Hubbard, L., \& Ruto, E. (2012). Determinants of technical efficiency in beef cattle production in Kenya. International Association of Agricultural Economists (IAAE) Triennial Conference, 1-25. https://doi.org/10.5897/ JDAE2013.0525

Oumarou, B., \& Huiqiu, Z. (2016). Technical Efficiency of Rice Farming in South-western Niger : A Stochastic Frontier Approach. Journal of Economics and Sustainable Development, 7(24), 58-65.

Pitt, M. M., \& Lee, L. F. (1981). The measurement and sources of technical inefficiency in the Indonesian weaving industry. Journal of Development Economics, 9(1), 43-64. https://doi.org/10.1016/0304-3878(81)90004-3

Pretty, J., \& Bharucha, Z. P. (2014). Sustainable intensification in agricultural systems. (1911), 1571-1596. https://doi. org/10.1093/aob/mcu205

Raburu, P. O., Okeyo-Owuor, J. B., \& Kwena, F. (2012). Community Based Approach to the Management of Nyando Wetland, Lake Victoria Basin, Kenya (First Edit). Mcpowl Media Ltd, Kenya.

Rugumamu, C. P. (2014). Empowering smallholder rice farmers in Tanzania to increase productivity for promoting food security in Eastern and Southern Africa. Agriculture \& Food Security, 3(7), 1-8.

Schuyt, K. D. (2005). Economic consequences of wetland degradation for local populations in Africa. Ecological Economics, 53(2005), 177-190. https://doi.org/10.1016/j. ecolecon.2004.08.003

Sekiya, N., Khatib, K. J., Makame, S. M., Oizumi, N., Araki, H., Sekiya, N., ... Tomitaka, M. (2013). Performance of a Number of NERICA Cultivars in Zanzibar, Tanzania: Yield, Yield Components and Grain Quality. Plant Production Science, 16(2), 141-153. https://doi.org/10.1626/pps.16.141
Sibiko, K. W. (2012). Determinants of common bean productivity and efficiency: a case of smallholder farmers in Eastern Uganda. Unpublished Thesis, Department of Agricultural Economics and Agribusiness Management, Egerton University, Kenya.

Styger, E. (2012). Evaluation of System of Rice Intensification (SRI) Program. Tanzania NAFAKA Project - Summary Trip Report Evaluation of System of Rice Intensification ( SRI ) Program: May 8 - May 20, 2012.

Thabethe, L., \& Mungatana, E. (2014). Estimation of Technical, Economic, and Allocative Efficiencies in Sugarcane Production in South Africa : A Case of Mpumalanga Growers. Journal of Economics and Sustainable Development, 5(16), 86-96.

Tolga, T., Nural, Y., Mehmet, N., \& Bahattin, Ç. (2009). Measuring the technical efficiency and determinants of efficiency of rice (Oryza sativa) farms in Marmara region, Turkey. New Zealand Journal of Crop and Horticultural Science, 37(2), 121-129. https://doi.org/10.1080/01140670909510257

Toma, E., Dobre, C., Dona, I., \& Cofas, E. (2015). DEA Applicability in Assessment of Agriculture Efficiency on Areas with Similar Geographically Patterns. Agriculture and Agricultural Science Procedia, 6(December), 704-711. https:// doi.org/10.1016/j.aaspro.2015.08.127

Turyahabwe, N., Kakuru, W., Tweheyo, M., \& Tumusiime, D. M. (2013). Contribution of wetland resources to household food security in Uganda. Agriculture \& Food Security, 2(5), 1-12.

Turyahabwe, N., Tumusiime, D. M., Kakuru, W., \& Barasa, B. (2013). Wetland Use / Cover Changes and Local Perceptions in Uganda. 2(4), 95-105. https://doi.org/10.5539/sar.v2n4p95

United Republic of Tanzania. (2007). Improved agricultural research technologies recommended in Tanzania. A report published by the Department of Research \& Training, Ministry of Agriculture, Food Security and Cooperatives, Dar Es Salaam, Tanzania. April 2007.

USDA. (2017). 2017 Tanzania corn, wheat, and rice. A report by Global Agricultural Information Network (GAIN) for United States Department of Agriculture on 29th March 2017.

Wakili, A. M., \& Isa, A. H. (2015). Technical Efficiency of Small Scale Rice Production in Adamawa State, Nigeria. International Conference on Chemical, Food and Environment Engineering (ICCFEE'15) Jan. 11-12, 2015 Dubai (UAE), 20-25.

Willy, D. K., Muyanga, M., \& Jayne, T. (2019). Can economic and environmental benefits associated with agricultural intensification be sustained at high population densities? A farm level empirical analysis. Land Use Policy, 81(2019), 100-110. https://doi.org/10.1016/j.landusepol.2018.10.046 
Wilson, R. T., \& Lewis, I. (2015). The Rice Value Chain in Tanzania. A report from the Southern Highlands Food Systems Programme, FAO.

Wood, A., Dixon, A., \& Mccartney, M. (2013). Wetland Management and Sustainable Livelihoods in Africa. eds., Wood, A.; Dixon, A.; McCartney, M.P. New York, USA: Routledge. Pp. 1-42.

Yang, Z., Mugera, A. W., \& Zhang, F. (2016). Investigating yield variability and inefficiency in rice production: A case study in Central China. Sustainability (Switzerland), 8(8), 1-11. https://doi.org/10.3390/su8080787 
